\title{
Dieback and growth loss of sugar maple associated with defoliation by the forest tent caterpillar
}

\author{
by H.L. Gross ${ }^{1}$
}

\begin{abstract}
Sugar maple (Acer saccharum Marsh.) stands in southwestern Ontario experienced a forest tent caterpillar (Malacosoma disstria $\mathrm{Hbn}$.) infestation in the mid 1970s. The defoliation was considered a key factor that accounted for an upsurge in the amount of dieback damage that occurred in 1977 and 1978 in the area affected by the caterpillar. Growth loss, dieback and food reserve relationships were examined. In the years 1977-1979 defoliated maples grew at a reduced rate that averaged $39.5 \%$ less than that for maples in stands adjacent to the infestation. Trees that recovered from the influence of defoliation were compared with those that died or continued to experience dieback. Those that recovered had greater food reserves in 1978 and 1979, on the basis of sapwood starch content, than did maples that declined. Stands showed good recovery from dieback. Dominant and codominant maples that had less than $40 \%$ branch mortality in 1978 generally recovered to good vigor and crown shape by 1980 .
\end{abstract}

\section{Introduction}

Sugar maple (Acer saccharum Marsh.) in Ontario has been experiencing crown deterioration for many years (Griffin 1965, Howse et al. 1981, Kondo and Taylor 1985, McLaughlin et al. 1985). The condition has been termed maple decline, maple dieback, maple blight or maple wilt, and the problem seems to occur throughout the range of sugar maple. Newspapers and magazines have featured the maple problem and this has increased public interest in what is happening to maple. Other broadleaved species, notably ash (Fraxinus spp.), beech (Fagus spp.), birch (Betula spp.) and oak (Quercus spp.) are also experiencing decline problems. Sugar maple is a major component of the Deciduous and the Great Lakes-St. Lawrence Forest Regions (Rowe 1972), and is highly valued for timber products, maple syrup production and esthetics.

Trees affected by diebacks and declines experience branch mortality, frequently progressive, that begins in the peripheral crown portions and this commonly results in death of the trees. Other symptoms are premature fall coloration, reduced foliar and wood growth, and the presence of pests that normally attack only weakened trees. Houston (1981) presented an excellent treatise on diebacks and declines. He described stress-related causal factors such as adverse weather, pest activity, pollution, etc., and noted that diebacks and declines are often a response to several types of stress. The combination of stress factors that operate at different sites can vary yet still produce the same symptoms and effects on trees. Maple blight studies at the University of Wisconsin (Geise et al. 1964) identified the importance of insect defoliation as a stress for maple.

\footnotetext{
${ }^{1}$ Forestry Canada, Ontario Region, P.O. Box 490, Sault Ste. Marie, Ontario P6A 5M7.
}

\section{Résumé}

Vers le milieu des années 70, des peuplements d'érables à sucre (Acer saccharum Marsh.) du sud-ouest de l'Ontario ont subi une infestation de la livrée des forêts (Malacosoma disstria $\mathrm{Hbn}$.). La défoliation a été considérée comme un facteur clé de l'accroissement des dommages associés au dépérissement en 1977 et 1978 dans la zone infestée. On a examiné les rapports entre la perte de croissance, le dépérissement et les réserves nutritives. De 1977 à 1979, la croissance des érables défoliés de la zone infestée a été inférieure en moyenne de $39,5 \%$ à celle des érables de peuplements adjacents. Les arbres qui se sont rétablis à la suite de la défoliation ont été comparés à ceux qui sont morts ou qui ont continué à dépérir. On a constaté que les réserves nutritives, mesurées par la teneur en amidon de l'aubier, étaient plus élevées en 1978 et 1979 chez les arbres qui se sont rétablis que chez les autres. Les peuplements se sont bien rétablis du dépérissement. En général, les érables dominants et codominants qui avaient moins de $40 \%$ de branches mortes en 1978 étaient vigoureux en 1980, et leur houppier avait une bonne conformation.
Dieback of sugar maple in the Ontario Ministry of Natural Resources' (OMNR) Algonquin and Southwestern Regions increased substantially in 1977 and 1978 as a result of a forest tent caterpillar (Malacosoma disstria $\mathrm{Hbn}$.) (FTC) infestation. Red maple (Acer rubrum L.) is not a preferred host of FTC, and did not sustain increased dieback. Herein, 'maple' refers to sugar maple.

The increase in dieback was noted first in Owen Sound District of the Southwestern Region. In 1976, several woodlot owners observed that their trees did not refoliate as vigorously as they had in previous years. They believed that some trees were dying. By the end of the 1977 growing season, patches of dead maples were observed in many woodlots. Forest owners and managers were concerned about the fate of the entire maple resource. Extensive mortality occurred during the 1977-1978 dormant season and many maples died in 1978 after producing a weak flush of foliage in the spring (Fig. 1). The influence of other kinds of stress was examined; however, no obvious cause of stress that was related to weather, the character of the site, or that was biological or chemical in nature (other than defoliation by FTC) was recognized as unique to the stands that experienced an upsurge in dieback. Maple stands adjacent to the FTC infestation did not experience a change in decline status.

The 1977 and 1978 annual reports of Forestry Canada's Forest Insect and Disease Survey (FIDS) (Howse et al. 1981, 1982) described the areas affected by FTC and dieback. An aerial survey conducted in September 1977 by FIDS staff from the Great Lakes Forestry Centre showed that the observed intensification of dieback was confined to stands in the area affected by FTC (Fig. 2). Ground surveys conducted to predict FTC population levels for 1978 confirmed the results of the survey and indicated that the FTC 


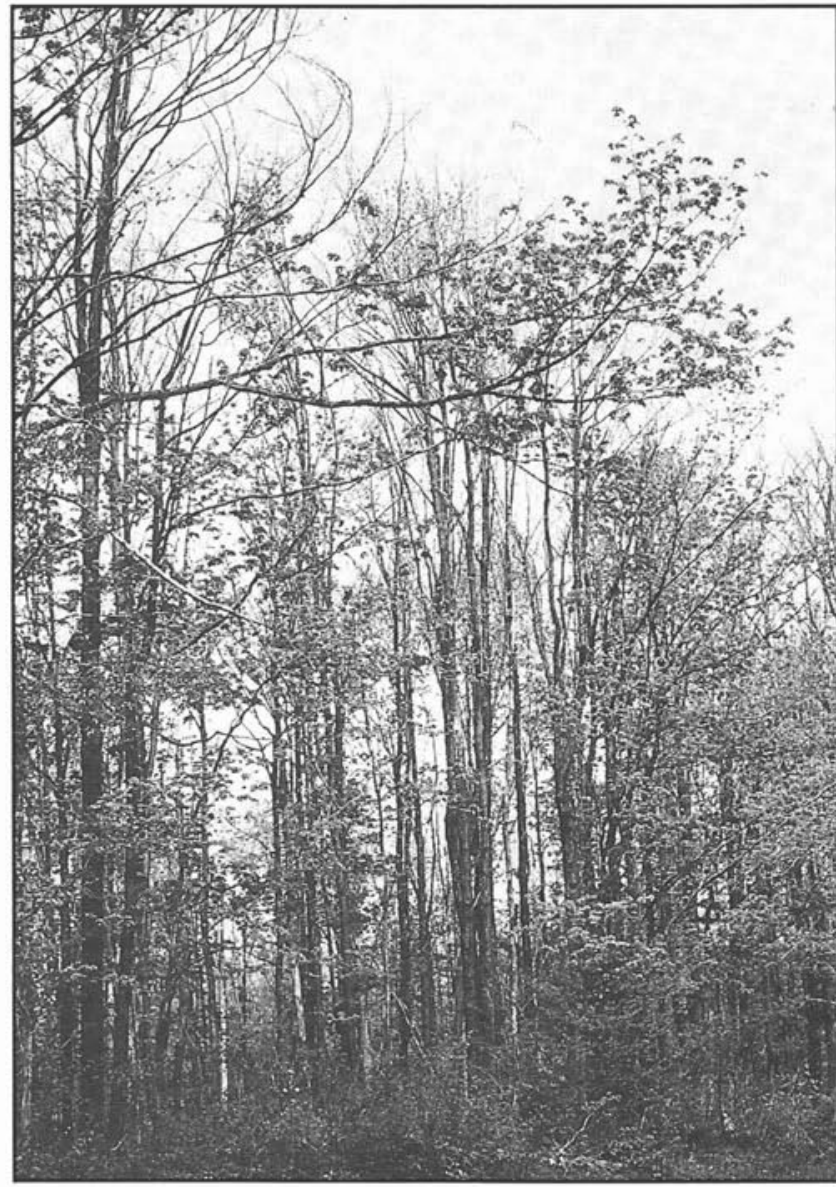

Figure 1. Extensive mortality and dieback in a maple stand near Owen Sound in 1978. The damage followed severe defoliation by the forest tent caterpillar.

infestation would probably subside, as it generally did in 1978. Stands scattered throughout the region had moderate defoliation in 1974 and 1975. Moderate or severe defoliation $(>50 \%)$ was common in many woodlots in 1976 and lighter defoliation was common elsewhere. Most maples and other FTC host trees were completely defoliated in 1977. By 1978 stands that had extensive patches of dead trees were common, and damage ranged from this extreme to little noticeable dieback. The general decline of maple that was evident to various degrees throughout its range (Howse et al. 1981) is a possible explanation for the varied response within the defoliated area.

A similar maple dieback problem occurred in Owen Sound District in the 1950s and early 1960s (Griffin 1965), and was attributed to unfavorable environmental conditions. The FTC infestation of the early 1950 s was thought to have had no appreciable influence on the affected trees (ibid.). In that instance most of the dieback occurred several years after the FTC infestation.

Defoliation predisposes trees to attack by agents that usually have little influence on healthy, vigorous trees (Houston 1981, Wargo 1981b). Chemical changes induced by defoliation in sugar maple favor the growth of Armillaria mellea (Vahl:Fr.) Kummer (Parker and Houston 1971, Wargo et al. 1972). As well, wounds tend to be larger and heal more slowly on defoliated than on unaffected sugar maples (Wargo 1977).

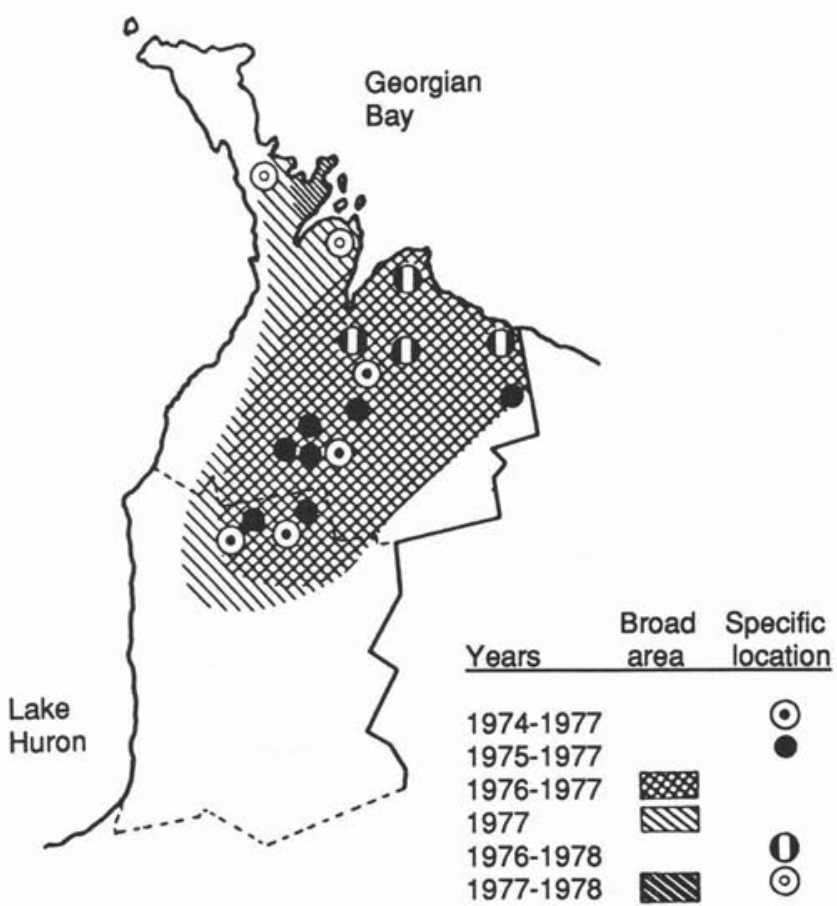

Figure 2. Areas in OMNR's Southwestern Region of Ontario defoliated by the forest tent caterpillar. Data are from several annual reports compiled by the Forest Insect and Disease Survey of Forestry Canada.

Considerable research has been done on the effects of defoliation on tree growth and vigor. This work is well summarized by Wargo (1981a,b,c). For maple, the deleterious effects of defoliation on radial, terminal and foliar growth, on tree vigor and on crown condition are usually correlated well with tree food reserves, as rated by the starch content of the roots (Parker and Houston 1971; Wargo et al. 1972; Wargo 1981a,b,c). Wargo (1981c) indicated that starch content is a function of the timing and severity of defoliation. Defoliation of maple in southern Ontario by FTC occurs from late May to mid-June. Severe defoliation that occurs early enough to allow trees to foliate again causes a severe food drain (Wargo 1981c), and in 1977 most maples in the area infested by FTC foliated again after complete defoliation.

The present study was begun early in 1978 to assess the impact of the defoliation by FTC and follow the progress of maple dieback. Dieback was expected to intensify in a manner similar to the occurrence of the maple dieback of the late 1950 s and early 1960 s that was observed by Griffin (1965). Wargo (1978) presented operational results of the use of starch content for risk rating the survival capacity of oaks. In the present study, I attempted to use Wargo's methods to rate the survival capacity of maples and to follow dieback trends for the defoliated trees.

\section{Methods}

Sample stands were selected randomly from lists compiled in consultation with OMNR foresters. Stands listed had $>50 \%$ sugar maple content. Most stands were on private lands managed by OMNR foresters under the Woodland Improvement Act or were on Crown land. A few stands were not listed because extensive mortality had so reduced the maple population that the remaining trees did not provide an 
Table 1. Descriptive statistics for a sugar maple stand affected by forest tent caterpillar defoliation in southwestern Ontario

\begin{tabular}{|c|c|c|c|c|}
\hline & \multicolumn{2}{|c|}{$\begin{array}{l}\text { Defoliated stands } \\
\quad(\mathrm{n}=18)\end{array}$} & \multicolumn{2}{|c|}{$\begin{array}{l}\text { Control stands } \\
(\mathrm{n}=5)\end{array}$} \\
\hline & Avg & Range & Avg & Range \\
\hline Age (yr) & 69 & $45-84$ & 77 & $70-80$ \\
\hline $\begin{array}{l}\text { Diameter }(\mathrm{cm}) \\
\text { Sugar maple } \\
\text { All species }\end{array}$ & $\begin{array}{l}23 \\
23\end{array}$ & $\begin{array}{l}14-33 \\
14-34\end{array}$ & $\begin{array}{l}23 \\
23\end{array}$ & $\begin{array}{l}17-27 \\
17-25\end{array}$ \\
\hline $\begin{array}{l}\text { Height }(\mathrm{m}) \\
\text { Sugar maple } \\
\text { All species }\end{array}$ & $\begin{array}{l}22 \\
21\end{array}$ & $\begin{array}{l}16-26 \\
16-26\end{array}$ & $\begin{array}{l}21 \\
21\end{array}$ & $\begin{array}{l}19-23 \\
19-24\end{array}$ \\
\hline Density (trees per ha) & 591 & $310-1055$ & 754 & $590-890$ \\
\hline $\begin{array}{l}\text { Species Content (\%) } \\
\text { Sugar maple } \\
\text { Other FTC hosts } \\
\text { Conifer } \\
\text { Red maple }\end{array}$ & $\begin{array}{r}79 \\
18 \\
2 \\
1\end{array}$ & $\begin{array}{r}45-97 \\
4-45 \\
0-16 \\
0-10\end{array}$ & $\begin{array}{r}69 \\
30 \\
1 \\
0\end{array}$ & $\begin{array}{c}55-90 \\
10-45 \\
0-1 \\
0-0\end{array}$ \\
\hline $\begin{array}{l}\text { Basal area }\left(\mathrm{m}^{2} / \mathrm{ha}\right) \\
\text { Sugar maple } \\
\text { All species }\end{array}$ & $\begin{array}{l}21 \\
26\end{array}$ & $\begin{array}{l}12-38 \\
16-43\end{array}$ & $\begin{array}{l}25 \\
36\end{array}$ & $\begin{array}{l}17-32 \\
27-47\end{array}$ \\
\hline $\begin{array}{l}\text { Total volume }\left(\mathrm{m}^{3} / \mathrm{ha}\right) \\
\text { Sugar maple } \\
\text { All species }\end{array}$ & $\begin{array}{l}225 \\
279\end{array}$ & $\begin{array}{l}143-418 \\
181-483\end{array}$ & $\begin{array}{l}256 \\
372\end{array}$ & $\begin{array}{l}179-331 \\
281-452\end{array}$ \\
\hline $\begin{array}{l}\text { Merchantable volume }\left(\mathrm{m}^{3} / \mathrm{ha}\right) \\
\text { Sugar maple } \\
\text { All species }\end{array}$ & $\begin{array}{r}85 \\
105\end{array}$ & $\begin{array}{r}7-278 \\
11-327\end{array}$ & $\begin{array}{l}102 \\
132\end{array}$ & $\begin{array}{l}56-141 \\
95-185\end{array}$ \\
\hline $\begin{array}{l}\text { Current annual increment }\left(\mathrm{m}^{3} / \mathrm{ha}\right) \\
\text { Sugar maple } \\
\text { All species }\end{array}$ & $\begin{array}{l}3.8 \\
4.7\end{array}$ & $\begin{array}{l}2.6-5.2 \\
3.4-5.9\end{array}$ & $\begin{array}{l}4.6 \\
6.7\end{array}$ & $\begin{array}{l}3.2-5.7 \\
5.2-8.6\end{array}$ \\
\hline $\begin{array}{l}\text { Annual growth loss 1977-1979 (\%) } \\
\text { Sugar maple }\end{array}$ & 39.5 & $31.8-46.7$ & n.a. & n.a. \\
\hline
\end{tabular}

Table 2. Regression models for dieback and growth loss relationships associated with defoliation by the forest tent caterpillar.

\begin{tabular}{|c|c|c|}
\hline Regression models & $\begin{array}{c}\text { Regression } \\
\text { coefficient }\left(R^{2}\right)\end{array}$ & $\begin{array}{c}\text { Standard } \\
\text { error }\end{array}$ \\
\hline $\begin{array}{l}\text { (1) } X_{2}=0.878 X_{3}+0.191 \\
\text { (2) } X_{1}=0.031 X_{2}+0.119 \\
\text { (3) } X_{6}=0.000413 X_{4}-0.000875 X_{5}+0.00035 \\
\text { (4) } X_{12}=-0.0177 X_{7}-0.00467 X_{8}+1.0568 \\
\text { (5) } X_{10}=-0.263 X_{11}+0.018\left(X_{11}\right)^{2}+0.979 \\
\text { (6) } X_{9}=-0.225 X_{11}+0.0140\left(X_{11}\right)^{2}+0.927\end{array}$ & $\begin{array}{l}0.972 \\
0.766 \\
0.726 \\
0.068 \\
0.590 \\
0.490\end{array}$ & $\begin{array}{l}0.21 \\
0.17 \\
0.0036 \\
0.398 \\
0.219 \\
0.238\end{array}$ \\
\hline \begin{tabular}{ll}
\multicolumn{2}{l}{ VARIABLES } \\
$X_{1}$ & Double-bark thickness at $1.3-\mathrm{m}$ height $(\mathrm{cm})$. \\
$X_{2}$ & Diameter (outside bark) at $1.3 \mathrm{~m}$ height $(\mathrm{cm})$. \\
$X_{3}$ & Diameter (outside bark) at $0.2 \mathrm{~m}$ height $(\mathrm{cm})$. \\
$X_{4}$ & Diameter (outside bark) at $1.3 \mathrm{~m}$ height in $1978(\mathrm{~cm})$. \\
$X_{5}$ & Crown class (DC $=1$, IS $=2)$. \\
$X_{6}$ & Average volume increment $(\mathrm{AVI})\left(\mathrm{m}^{3}\right)$. \\
$X_{7}$ & Total tree height $(\mathrm{m})$. \\
$X_{8}$ & DBK in 1980. \\
$X_{9}$ & DBK in 1979. \\
$X_{10}$ & DBK in 1978. \\
$X_{11}$ & Percentage of starch content $(\mathrm{SCH})$ in sapwood in 1978. \\
$X_{12}$ & Volume increment $1977-1979$ as a proportion of AVI.
\end{tabular} & & \\
\hline
\end{tabular}

adequate sample base. Eighteen defoliated stands were sampled in the Owen Sound and Wingham districts. Five stands, designated as controls, were sampled in the portion of Wingham District that was unaffected by FTC defoliation.

Mortality and Dieback. A minimum of 80 maples in each stand were sampled in 10 or more randomly located $200-\mathrm{m}^{2}$ $(6.0 \times 33.3 \mathrm{~m})$ plots. The following parameters were recorded for all trees $>5 \mathrm{~cm}$ in diameter: species, diameter at $1.3 \mathrm{~m}$ height, total height, merchantable height $(18 \mathrm{~cm}$ top diameter), crown class and percentage of dead crown (DBK). Annual defoliation, foliage color and foliage size were rated but were dropped from the analysis. Defoliation after 1977 was negligible in the study stands. Abnormal foliar color was rare, and foliage smaller than normal was observed only occasionally. Stands were examined early in 1978, as buds were flushing, and again in August. Thereafter, visits were made each summer through 1982. 
DBK was an estimate of the percentage of crown volume with dead branches that retained most of the small twigs; these twigs were the shoots produced in the last year a branch grew. Experience indicated that small twigs were retained for about two years after death. Old dead branches were ignored. Trees were rated in six DBK classes: 1) DBK = $0-5 \%, 2) \mathrm{DBK}=6-20 \%, 3) \mathrm{DBK}=21-40 \%, 4) \mathrm{DBK}=$ $41-60 \%, 5)$ DBK $>60 \%$ and 6) dead tree. Classes 4 and 5 were combined to illustrate a category of $>40 \%$ DBK for some of the graphics in the present paper. The midpoint of the range of DBK in a class was used for some of the analyses.

The total number of trees sampled was 3,884. Data are presented for trees in the dominant and codominant crown classes (DC) and the intermediate and suppressed crown classes (IS) in order to remove the latter classes from certain comparisons, as they are not a major stand component in value or biomass. The defoliated population had 1,213 DC and 1,212 IS maples and 250 DC and 390 IS trees of other host species. The control population had 241 DC and 213 IS maples, and 122 DC and 37 IS trees of other host species. Other host species were: ash (mostly Fraxinus americana L.), basswood (Tilia americana L.), beech (Fagus grandifolia Ehrh.), birch (Betula alleghaniensis Britton and Betula papyrifera Marsh.), ironwood (Ostrya virginiana K. Koch), oak (mostly Quercus rubra L.) and aspen (Populus tremuloides Michx.). Data for 60 elm (Ulmus americana L.), 34 red maple and 112 conifer trees enter the analysis only for items such as stand density. Red maple and conifers were considered non-hosts. Elms were excluded because $60 \%$ died from 1977 to 1982. Dutch elm disease (Ceratocystis ulmi (Buism.) C. Moreau) was the principal cause of death, and inclusion of these data would have distorted the data with respect to FTC impact.

Descriptive stand data are given in Table 1. Logging history was such that most stands were about 80 years old. However, two stands aged 45 and 50 years were among the defoliated stands selected.

Starch and Growth. The defoliated maples selected for the starch and growth-loss aspects of this study were selected from the 12 defoliated stands for which permission was obtained to extract increment cores. Trees were selected by the process of stratified random sampling. Stratification was applied by selecting one DC and one IS tree for each of the DBK classes 1 through 5 in each stand. Some stands had no candidates in some of the more severe DBK classes and the number of maples actually sampled was 47 DC and 58 IS trees. All DBK/crown-class groupings contained at least 5 trees. The control sample used for growth analysis contained 23 DC and 31 IS maples. The control stand sample had only $10 \mathrm{DC}$ maples with dieback and these were all in class $2(6-20 \%$ DBK). Selection attempted to include 2 DC and 2 IS trees for DBK class 2 and 4 each for DBK class 1. A few trees were lost to logging and blowdown.

Parameters recorded for each tree were: diameter at 0.2 and $1.3 \mathrm{~m}$ height, bark thickness at $1.3 \mathrm{~m}$ height, annual radial growth from 1964 to 1982 at $0.2 \mathrm{~m}$ height, and starch content at $0.2 \mathrm{~m}$ height.

Starch contents (SCH), as a percentage of oven-dry weight, were determined by the methods of Wargo (1975) except that content was rated at $40 \mathrm{X}$ magnification for thin $(0.1-\mathrm{mm})$ cross-sections sliced from increment cores taken at $0.2 \mathrm{~m}$ height and frozen at $-10^{\circ} \mathrm{C}$ until processed. Wargo's method is an iodine-stain technique that imparts a purple color to starch, which is then quantified visually. Trees were sampled for SCH after leaf fall in late September. Wargo's (1975) SCH categories were interpreted and set as follows: high = $18 \%$, medium $=9 \%$, low $=6 \%$, very low $=3 \%$ and depleted $=1 \%$. These scores, rather than the range in $\mathrm{SCH}$ presented by Wargo, were used for statistical analysis. The scores assigned were graphically interpreted from a plot of the ranges in $\mathrm{SCH}$ content presented by Wargo.

The sample site at $0.2 \mathrm{~m}$ height on the bole was used to minimize damage to the merchantable portion of the bole and because extracting a core at this level was easier than coring the trees at the root collar or on a root. This provided material for both growth and $\mathrm{SCH}$ estimates from one site. Wargo (1976) showed that the most precise site for $\mathrm{SCH}$ ratings was on a root $0.2 \mathrm{~m}$ distal to the root collar. A preliminary study of 11 trees in various DBK classes showed no visibly detectable $\mathrm{SCH}$ difference for samples taken at $0.2 \mathrm{~m}$ height, at the root collar, and $0.2 \mathrm{~m}$ distal to the root collar. SCH at $1.3 \mathrm{~m}$ height was lower in some instances. Measurements of $\mathrm{SCH}$ by chemical extraction of these cores was well correlated $(r>0.950)$ with the visual ratings by workers involved in the study. In addition, for 57 trees, $\mathrm{SCH}$ at $0.2 \mathrm{~m}$ height was compared with $\mathrm{SCH} 0.2 \mathrm{~m}$ distal to the root collar in 1978. Starch content was the same for 46 trees, and differed by only one SCH class for 11 trees.

Annual growth was estimated on the basis of cores extracted at $0.2 \mathrm{~m}$ height, and processed on a growthmeasuring device at $40 \mathrm{X}$ magnification. Inside-bark diameter at $0.2 \mathrm{~m}$ height was transformed to outside-bark diameter at $1.3 \mathrm{~m}$ height on the basis of relationships established for the 57 trees mentioned above (models [1] and [2], Table 2). Total annual volume increments were based on a local-volume equation (Morawski 1971, site region 6). To conserve space, several general terms have been given specific meanings in the present paper: "volume", is total gross cubic volume, "expected growth" is the average annual volume increment for the $1964-1973$ period that preceded the FTC infestation and "growth" is growth for the period of reference expressed as a proportion of expected growth.

Analysis. Regression analysis used the stepwise-forward method for selecting variables. The significance level for variables to enter a model was $\alpha=0.1$ and was $\alpha=0.05$ for retention. ANOVA, and the Brown-Forsythe test used for within-group comparisons, was conducted with the BMDP computer program (Dixon 1983).

\section{Results}

Mortality and Dieback. Most of the trees affected by the dieback associated with defoliation caused by FTC recovered by 1980 (Figs. 3-4) or were dead. There was very little change in status from 1980 through 1982 and data for 1981 and 1982 are not presented.

During the $1978-1980$ study period mortality totaled $2 \%$ for the DC and $14 \%$ for the IS maples in defoliated stands. In comparison, no mortality occurred for the DC maples in control stands and mortality of IS maples was only $2 \%$ (Fig. 3). Only $3 \%$ of the DC and $5 \%$ of the IS maples 


\section{Sugar Maple}

Intermediate + Suppressed
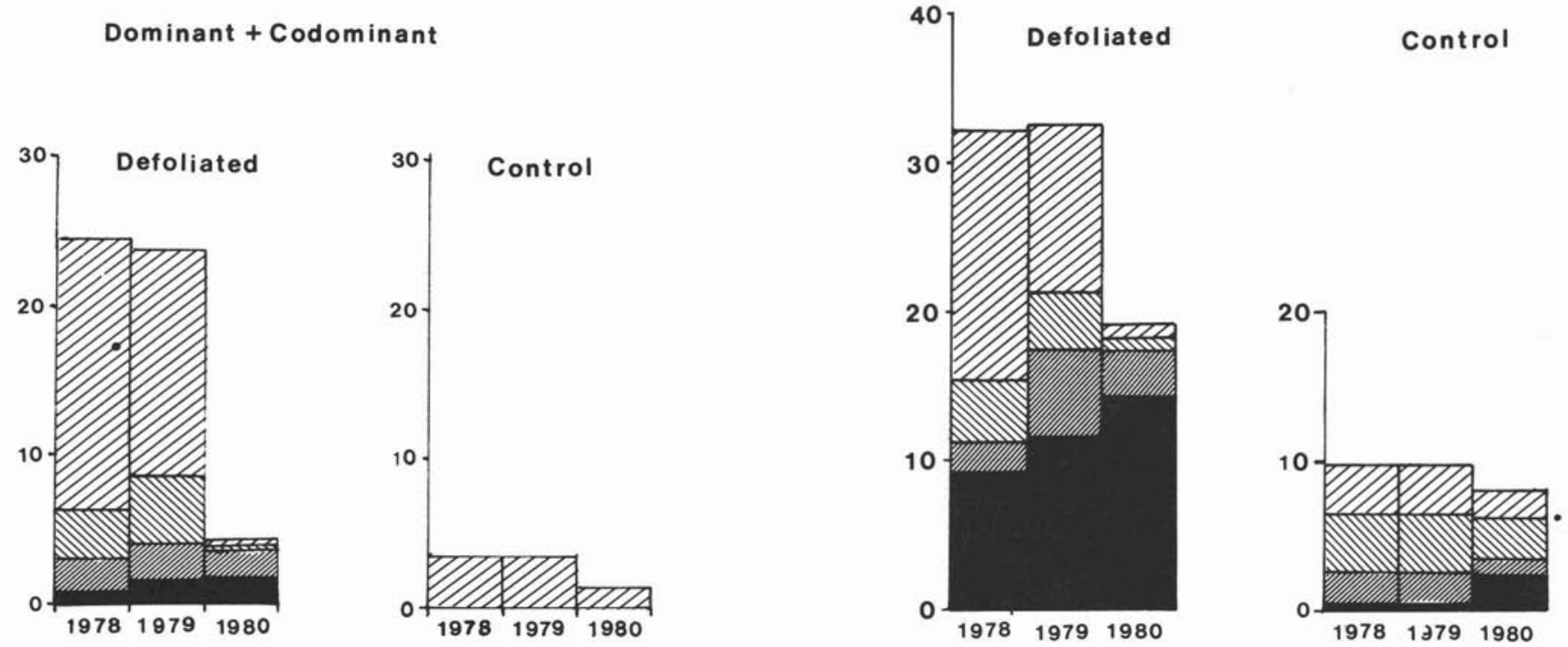

\section{Legend}

Percent Dieback
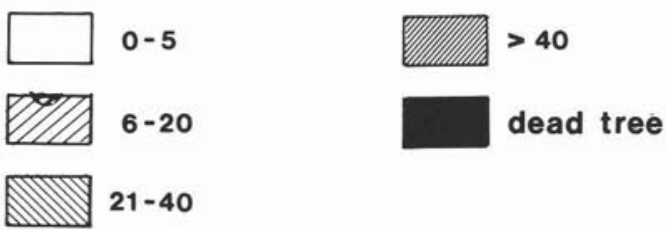

Figure 3. Annual dieback status of sugar maple in stands defoliated by the forest tent caterpillar in comparison with stands that were not defoliated. Data are shown as the percentage of the total sample in each category, except that the healthy category ( $0-5 \%$ dieback) is to be interpreted as the remaining percentage up to $100 \%$.

continued to have dieback problems in 1980 in the defoliated stands. In the control stands $1 \%$ of the DC and $6 \%$ of the IS maples showed dieback in 1980.

The good health of maple in the control stands was impressive (Fig. 3). Only $3 \%$ of the DC maples in the control stands showed dieback in 1978 compared with $24 \%$ in defoliated stands and $18 \%$ for other host species in the control stands (Fig. 3 and 4). Expansion of the control sample was considered. A reconnaissance of the next five random selections disclosed similar good health, and the initial five-stand selection was considered representative.

The dieback status of FTC host species other than maple was similar for DC trees in the defoliated and control stands (Fig. 4). The status of IS trees was considerably worse in the defoliated stands than in control stands (Fig. 4). Mortality for the 1978-1982 period was about $2 \%$ for DC trees in both situations, but was $14 \%$ for IS trees in defoliated stands compared with $3 \%$ in control stands. The dieback status of these other species showed improvement similar to that of maple by 1980 in the defoliated stands, but in the control stands improvement was not as impressive (Fig. 4).

The amount of dieback present in 1979 was very similar to that observed in 1978 for all comparisons (Fig. 3 and 4). Since the small twigs that formed the basis for DBK ratings usually remained attached for two years, the similarity of
DBK in 1978 and 1979 was evidence that the bulk of the dieback occurred in 1977 and early 1978. DBK ratings in 1980 reflected change, as most of the dead small twigs had been shed by then.

Data were examined to compare the recovery capacity of trees in each DBK class by comparing dieback status in 1980 with that in 1978. DC and IS trees in class 1 (0-5\% DBK) remained healthy for 99 and $96 \%$ of the maples and 97 and $96 \%$ of the other host trees, respectively. The destiny of maples in other DBK classes is illustrated in Figure 5. Clear areas above the shaded portions of a bar in Figure 5 indicate the percentage of maples that recovered to class 1 status by 1980 . The percentage that declined, remained static, or improved with respect to DBK can be interpreted from the bar graph. For example, of the $220 \mathrm{DC}$ maples that had $21-40 \%$ DBK in $1978,81 \%$ recovered to class $1(0-5 \%$ DBK), $2 \%$ improved to class 2 (6-20\% DBK), $2 \%$ remained static, $10 \%$ declined to over $40 \%$ DBK, and $5 \%$ died. Most of the DC and IS maples that had more than $40 \%$ DBK in 1978 died or remained static through 1980 . Trees of the other host species experienced a similar pattern of recovery.

Growth. Annual growth during the pre-infestation period of reference (1964-1973) was fairly constant (Figs. 6 and 7). The expected growth was a function of diameter and crown 


\section{Other Hosts}

Intermediate + Suppressed

Defoliated

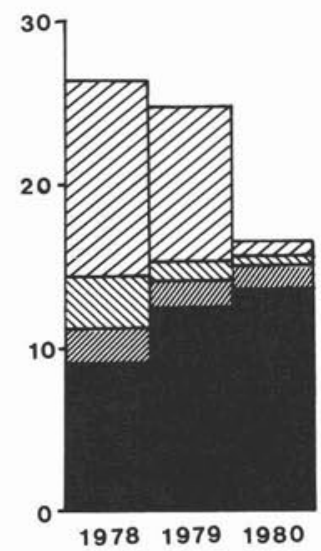

Control

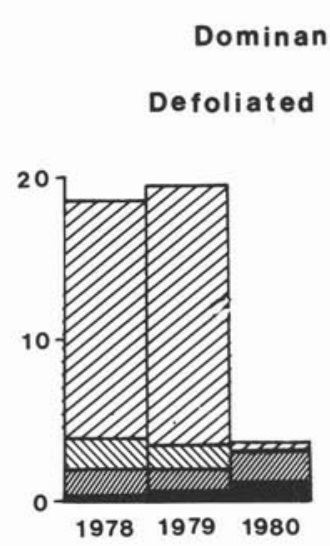

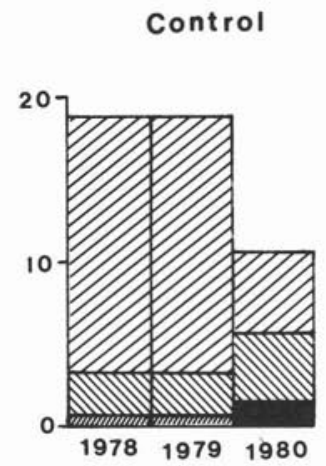

30

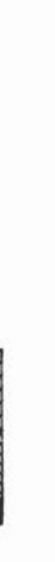

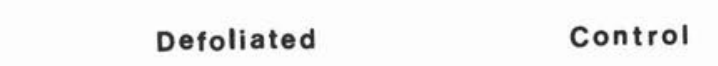

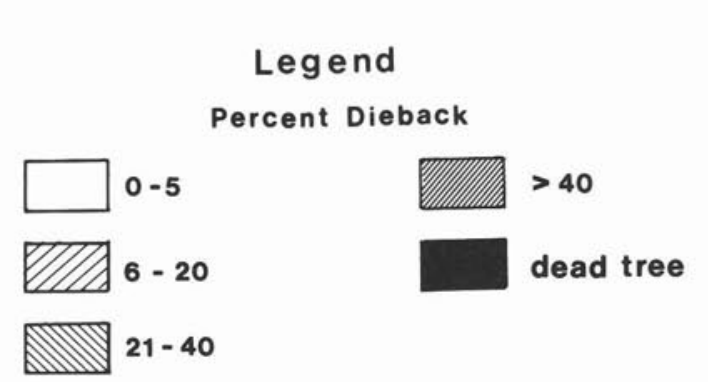

Figure 4. Annual dieback status of host species other than maple in stands defoliated by forest tent caterpillar in comparison with stands that were not defoliated. Data are shown as the percentage of the total sample in each category except that the healthy category (0-5\% dieback) is to be interpreted as the remaining percentage up to $100 \%$.

class (model [3] and Table 1). The defoliated DC maples grew at $64 \%$ of the expected rate of growth from 1977 to 1979 , when growth was significantly reduced $(\alpha \geq 0.05)$, compared with growth of $103 \%$ of the expected value by the DC control maples (Fig. 6). Growth by the defoliated IS maples was significantly lower $(\alpha \geq 0.05)$ than that of the control sample from 1975 to the end of the study (Fig. 7). Growth by the defoliated IS maples from 1977 to 1979 was $71 \%$ of expected growth. Almost half $(48 \%)$ of these trees died during the study. Growth of the survivors appears to have recovered to predefoliation levels (Fig. 7). Many of the IS trees in the control sample grew at an enhanced rate from 1975 to 1982 .

The growth rate depression for defoliated trees for the 1977-1979 period was directly proportional to tree size and the amount of dieback present in 1980 (model [4], $\alpha=0.05$, $\mathrm{R}=0.068$ and Table 1). A better model had been expected on the basis of an anticipated strong relationship between growth and both SCH and DBK. Estimating the actual amount of growth loss presented a dilemma, as the model was not especially good for predictive purposes. However, the model included DBK as a variable and this cautioned against basing the estimate on an average derived from sample data that was stratified on the basis of DBK. Since the variance accounted for by model [4] was significant, and the inclusion of DBK in 1980 as a regressor variable compensated somewhat for stratification, model [4] was used as the basis for estimating growth impact.
Growth loss for maples affected by FTC in the Owen Sound and Wingham districts was estimated at $220,000 \mathrm{~m}^{3}$. Model [4] was applied to tree data for each stand to get an estimate of growth loss for the 1977-1979 period. Growth loss was a function of the reduced growth of defoliated trees and the somewhat better than expected growth by DC maples in control stands. The estimated average stand loss was $39.5 \%\left(1.5 \mathrm{~m}^{3} / \mathrm{ha}\right)$ of expected maple growth (Table 1$)$.

It should be noted that both the DC and the IS groups illustrated in Figures 6 and 7 were stratified samples and thus contained a larger portion of trees with considerable DBK than would be expected for a simple random sample. All the defoliated trees exhibited growth depression from 1977 to 1979, including 19 trees that were rated healthy (DBK class $=1$ ). Consequently, Figures 6 and 7 are representative of the total DC and IS populations. Several comparisons, including plots of growth by defoliated trees in each DBK class, supported this observation.

Some growth depression was present in 1978 for all comparisons (Figs. 6-9). This seemed to be a reflection of a mild drought. Data from the Wiarton weather station indicate that rainfall was about $50 \%$ less than normal from mid-June to mid-August 1978.

The DC maples that recovered grew at a reduced rate $(\alpha$ $=0.05$ ) in 1977 in comparison with those that declined (Fig. 8). The DC trees that declined grew at $97 \%$ of the expected rate in 1977, an indication of normal growth in a year of intense defoliation. Trees that ultimately recovered 


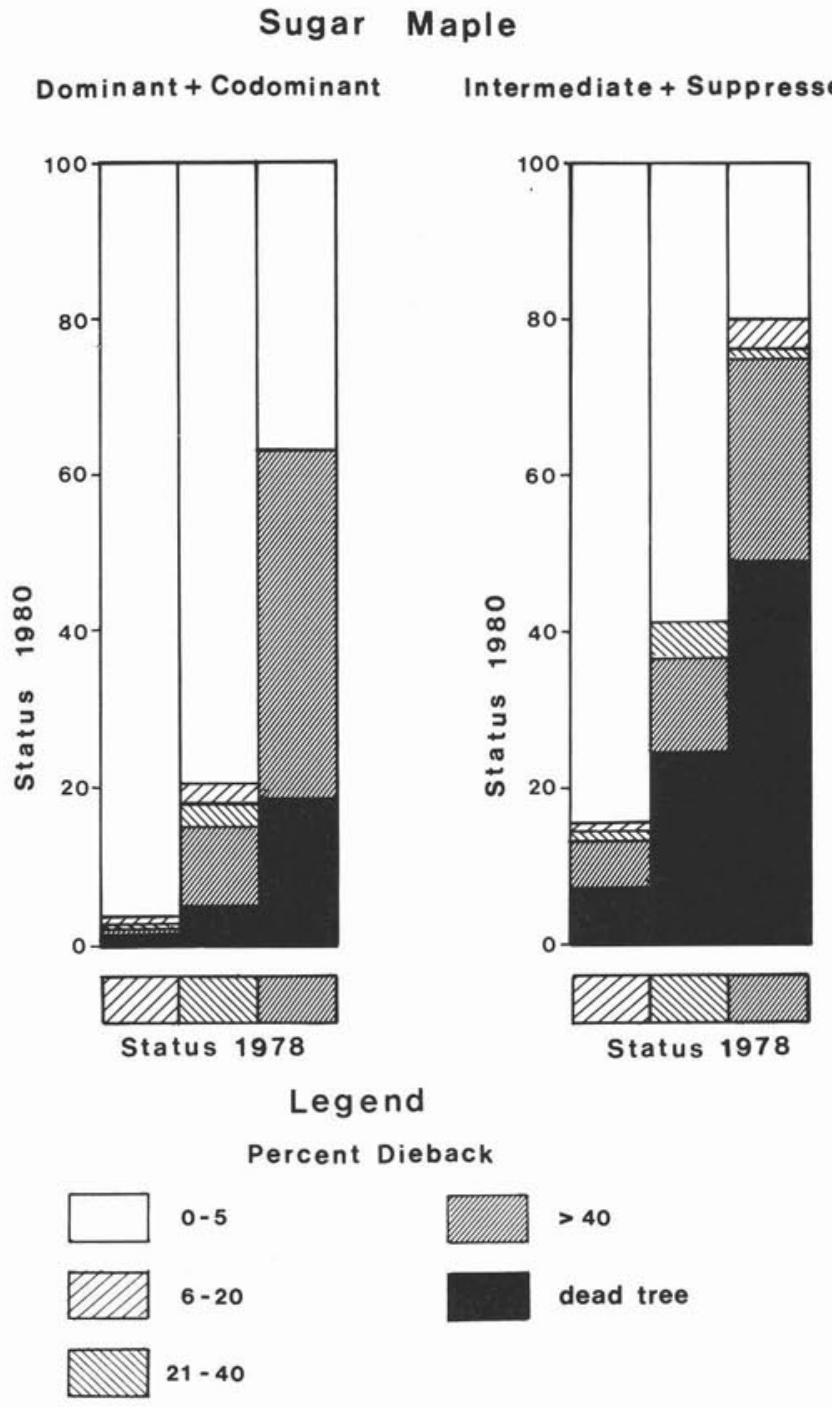

Figure 5. The fate (i.e., the amount of dieback remaining in 1980) of sugar maples with various amounts of dieback in 1978. The maples in the healthy (0-5\% dieback) category remained healthy and are not illustrated.

grew at only $54 \%$ of the expected rate. Growth in 1977 by the IS maples was similar (Fig. 9). IS trees that recovered were growing at an enhanced rate prior to the infestation and show an earlier and greater growth reduction compared with trees that declined (Fig. 9). This differential growth response in both DC and IS groups no doubt contributed to the high variance encountered in model [4].

Shoot growth was not monitored for each tree sampled because the resources and time required to gain access to tree crowns were unavailable. However, shoot growth was of interest and general observations were recorded. Growth was reduced in 1978, and internodes were short for most trees, including those classed as healthy. Foliage was usually of normal size, but severely affected trees often had branches that produced foliage at only a few bud sites. Growth in 1979 was vigorous, especially for shoots on trees that had experienced considerable dieback and were recovering. Growth for 1980 through 1982 was normal.

Starch Reserves. For the defoliated maples, SCH was inversely proportional to DBK. Models [5] and [6]
(Table 2) show the relationship for 1978 and 1979. The amount of starch present at the end of the 1978 growing season was well correlated $(r \geq 0.675)$ with the dieback status of trees in 1978, 1979 and 1980. In $1979 \mathrm{SCH}$ was almost as well correlated ( $\mathrm{r} \geq 0.500$ ) with DBK in 1979 and 1980 as was SCH in 1980 with DBK in 1980 . Models and correlations for data grouped by IS and DC tree size were similar. No meaningful SCH-DBK analysis seemed practical for the control stands, as few maples in these stands experienced dieback.

Maples that recovered or remained healthy had significantly greater $(\alpha=0.01)$ food reserves in 1978,1979 and 1980 than those that did not recover. Maples in the combined IS and DC group rated as DBK class 1 "healthy" in 1980 had average SCH values in 1978,1979 and 1980 of $6.0,4.7$ and $5.0 \%$, respectively, compared with values of $2.0,2.4$, and $1.6 \%$ for trees that did not recover. DC trees that recovered had SCH values in 1978 and 1979 that were about $25 \%$ greater than those of the IS group that recovered; otherwise, data for both groups are similar.

Dying trees and trees with $>60 \%$ DBK almost invariably had depleted food reserves $(\mathrm{SCH} \leq 1 \%)$. Low food reserves $(\mathrm{SCH}=3 \%)$ seemed adequate for survival as numerous trees with low $\mathrm{SCH}$ remained vigorous or recovered to good health (DBK Class 1).

\section{Discussion}

FTC defoliation seemed to be a key factor responsible for the increase in maple decline that occurred in the late 1970s in the Southwestern Region of Ontario. Most of the $410,000 \mathrm{~m}^{3}$ mortality reported by Gross (1985) occurred in 1977 and the early part of 1978 . There was a lag of several years for crown recovery and growth rate recovery, but the amount of damage did not increase substantially and by 1980 most stands had recovered to pre-infestation status. Stands that experienced extensive mortality were exceptions; however, even in these stands, surviving trees appeared vigorous by 1980 . In contrast, the occurrence of maple dieback in the late 1950s and early 1960s (Griffin 1965) began several years after a FTC infestation and seemed to intensify for several years. This suggests that FTC defoliation may have had a reduced role in that occurrence of dieback.

Although FTC defoliation was a key factor in the occurrence of dieback in the stands defoliated in the 1970s, there were probably other contributing factors. Impact in the stands varied widely from extensive mortality to very little dieback. It seemed that the more general dieback situation for maple in Ontario (Howse et al. 1981, McLaughlin et al. 1985, Kondo and Taylor 1985) was intensified in those areas where FTC was active.

Forest managers can consider $>40 \%$ DBK to be critical. These trees often had large sections of dead crown whereas on trees with less dieback damage was usually confined to smaller branches in the peripheral parts of the crown. The large dead branches are likely to provide infection courts for heart-rot organisms. DC maples with DBK $>40 \%$ experienced $18 \%$ mortality and $44 \%$ continued to show considerable dieback in 1980 (Fig. 5). In the $21-40 \%$ DBK class, $5 \%$ died and $15 \%$ continued to show dieback in 1980, and for the less severe DBK classes, mortality was negligible and virtually all trees recovered to Class 1 (0-5\% DBK) by 1980 (Fig. 5). Thus, data from this study indicates that trees with greater than $40 \%$ DBK should be salvaged. 


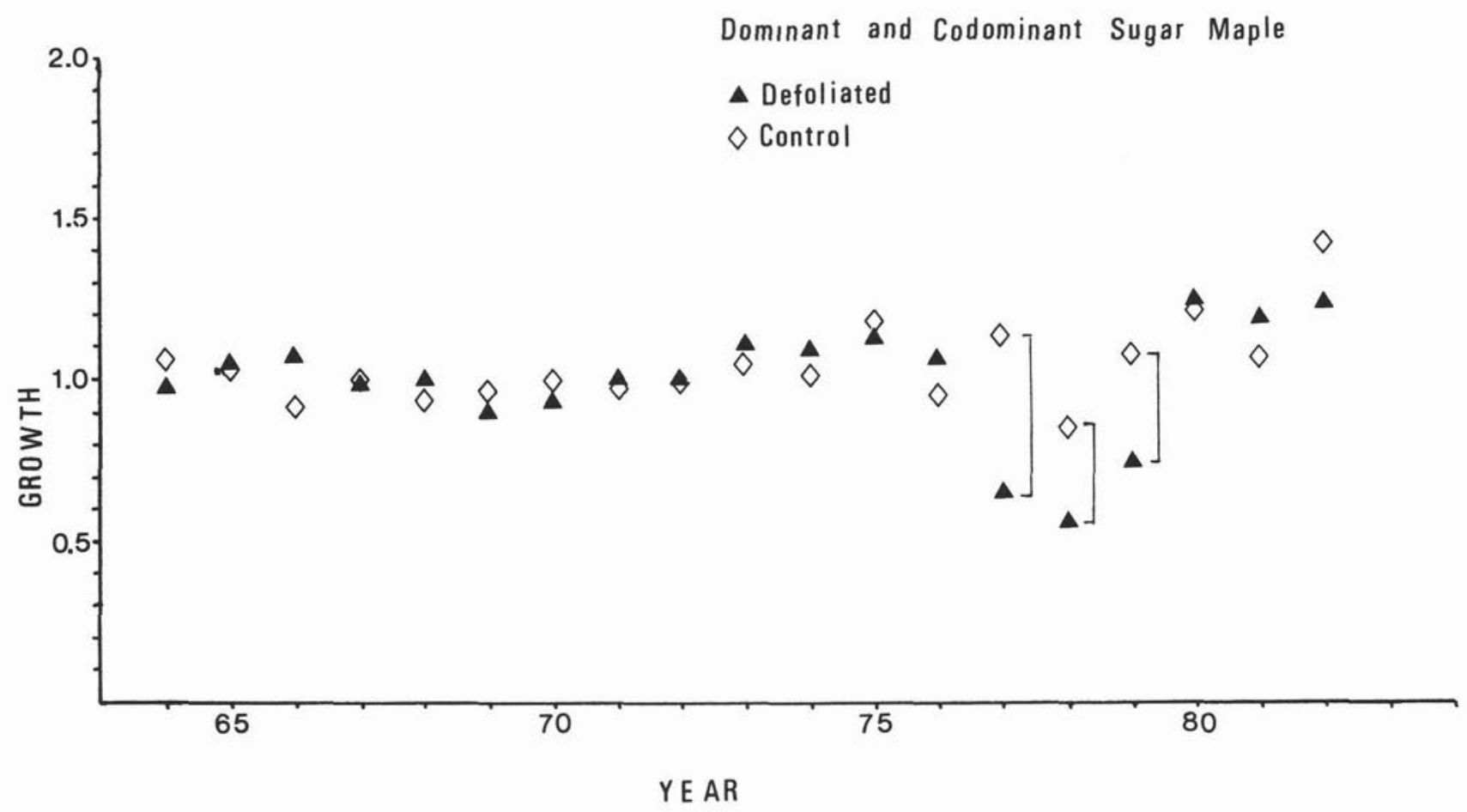

Figure 6. Growth by dominant and codominant sugar maple, presented as a proportion of the average volume increment for the period 1964-1973: a comparison of trees defoliated by the forest tent caterpillar in the mid 1970 s $(\Lambda, n=47)$ with undefoliated control trees $(\diamond, n=23)$. Differences that are significant at $\alpha=0.05$ are separated by a line. Data for seven defoliated trees that died were removed from the data base after the year of death.

\section{Intermediate and Suppressed Sugar Maple}

\section{- Defoliated \\ $\diamond$ Control}

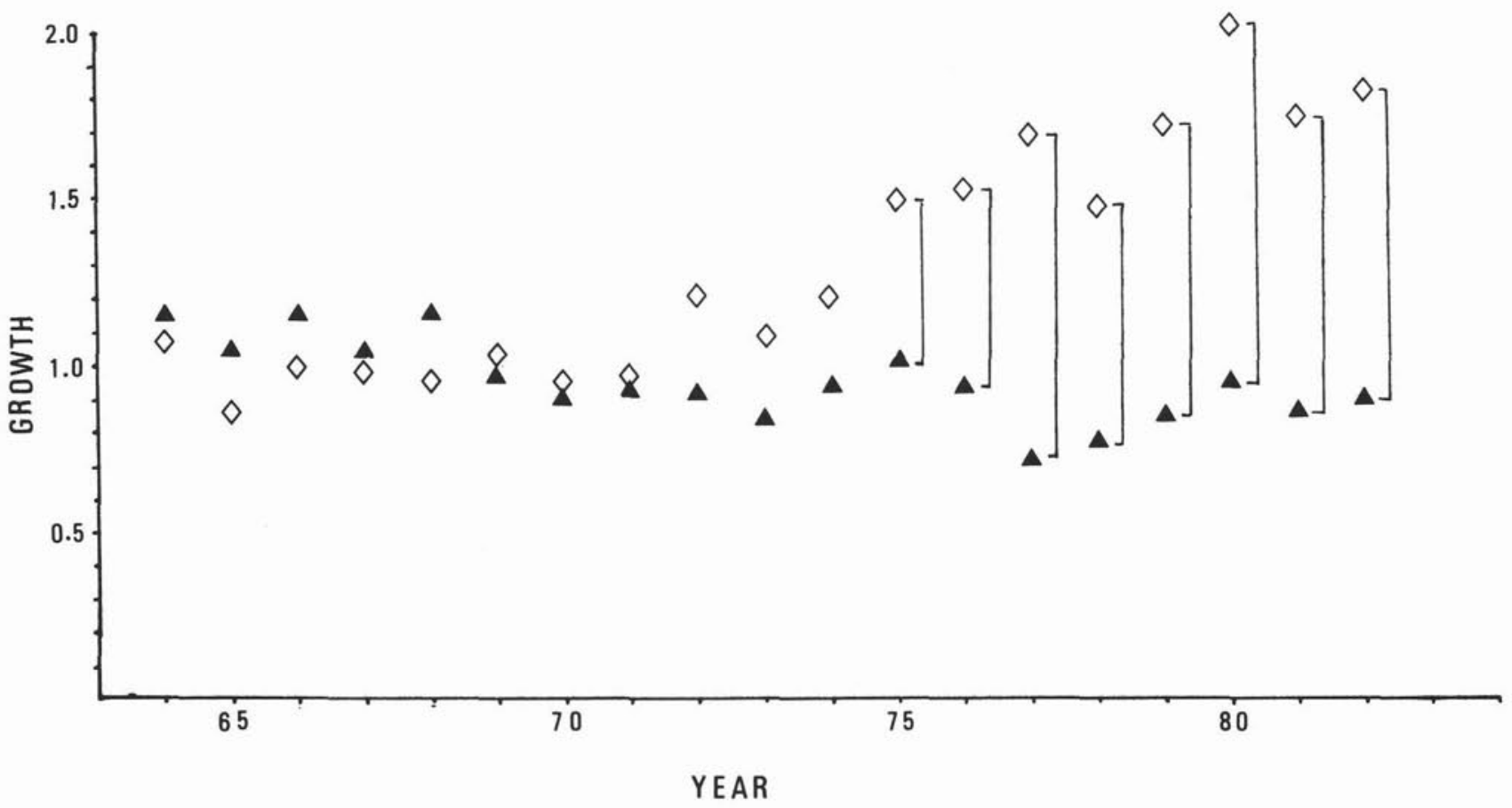

Figure 7. Growth by intermediate and suppressed sugar maples, presented as a proportion of the average volume increment for the period 1964-1973: a comparison of trees defoliated by the forest tent caterpillar in the mid 1970s $(\Delta, n=58)$ with undefoliated control trees $(\diamond, n=31)$. Differences that are significant at $\alpha=0.05$ are indicated by a vertical line. Data for 28 defoliated trees that died were removed from the data base after the year of death. 


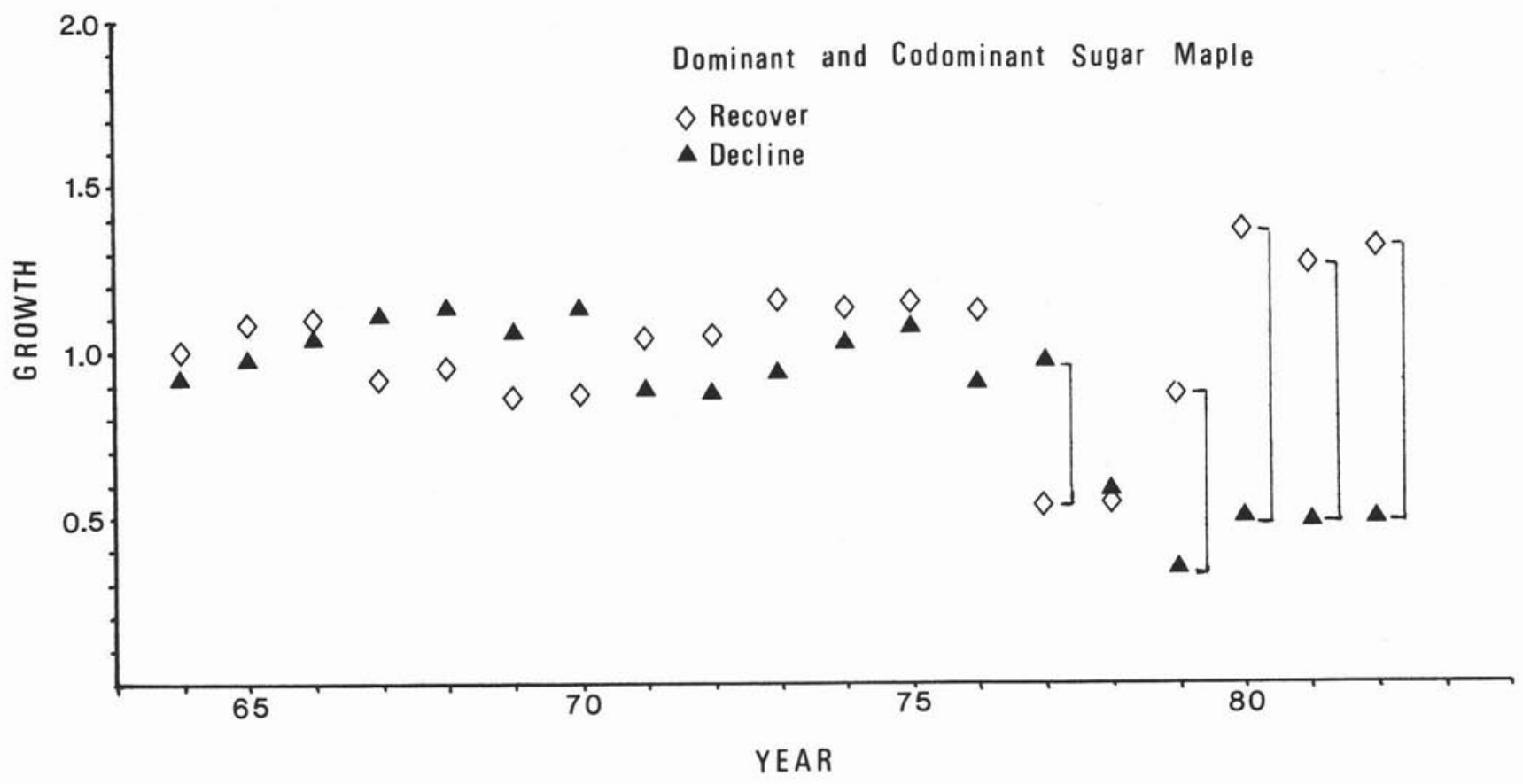

Figure 8. Growth by the dominant and codominant sugar maples that were defoliated by the forest tent caterpillar, presented as a proportion of the average volume increment for the period 1964-1973: a comparison of those that recovered to healthy crown status $(\diamond, \mathrm{n}=36)$ with those that continued to decline through $1980(\Delta, \mathrm{n}=11)$. Trees that declined and died $(\mathrm{n}=7)$ were removed from the data base after the year of death. Differences that are significant at $\alpha=0.05$ are indicated by a vertical line.

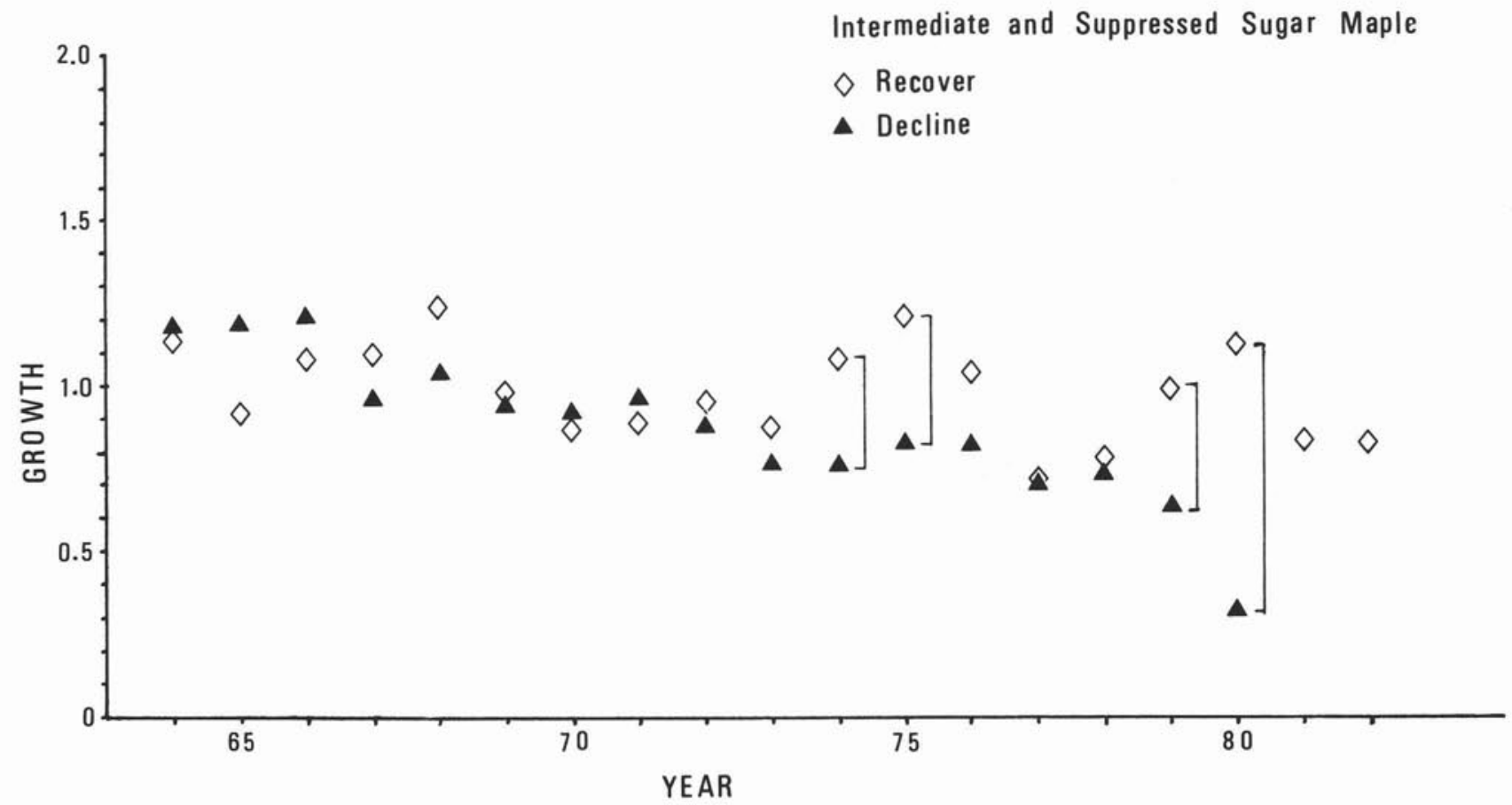

Figure 9. Growth by intermediate and suppressed sugar maples that were defoliated by the forest tent caterpillar in the mid 1970s, presented as a proportion of the average volume increment for the period 1964-1973: a comparison of those that recovered to healthy crown status ( $\diamond, \mathrm{n}=29)$ with those that continued to decline through $1980(\Lambda, n=29)$. Trees that declined and died $(n=28)$ were removed from the data base after the year of death. Data for the decline group are not presented for 1981 and 1982 as only one tree remained living. Differences that are significant at $\alpha=0.05$ are separated by a line.

This study and the literature (Parker and Houston 1971; Wargo et al. 1972; Wargo 1981a,b,c) suggest that SCH is highly sensitive to defoliation and dieback. Models [5] and
[6] (Table 2) are highly acceptable statistically on the basis of $\alpha=0.001$ and $\mathrm{R}^{2}$ values of 0.590 and 0.490 , respectively. These statistics, however, rate the probability that a 
relationship exists and the percentage of variability accounted for by the models, respectively. A relationship was virtually assured by the information provided by previous studies (ibid.). A goal of this study was to use $\mathrm{SCH}$ to predict recovery and survival. Data were highly variable for $\mathrm{SCH}$ in relation to DBK as indicated by the standard error of 0.219 DBK for model [5]. The predictor quality of the $\mathrm{SCH}$ models was such that confidence intervals for DBK were large. Similarly, the sample size required to provide reasonably precise estimates of $\mathrm{SCH}$ was also large. $\mathrm{A} \mathrm{SCH}$ level above which DBK was negligible was not evident. Low starch content $(\mathrm{SCH}=3 \%)$ seemed adequate for survival and recovery. Ability to withstand additional stress, such as defoliation, was not tested. Numerous trees with low starch content did recover, and several nonparametric tests indicate that the relationship is significant $(\alpha=0.01)$. Again, variability was a problem and exceptions to the $3 \% \mathrm{SCH}$ rule (i.e., negligible or excessive DBK and mortality) for trees with above and below this level of SCH were encountered. Development of a rule that has an acceptable confidence interval will require additional informative variables. Meanwhile, I suggest that one could accept that a good potential for survival exists if trees have $\mathrm{SCH} \geq 3 \%$, and that sample design can focus on the sample size required to predict that an acceptable proportion of the population has this content of starch.

In many respects the results of this attempt to rate the ability of maple to recover from dieback on the basis of $\mathrm{SCH}$ are similar to the findings of Wargo (1978), who applied his methodology to hazard rating of oaks that were being defoliated by gypsy moth (Lymantria dispar L.). He believed that additional information about severity of defoliation, crown condition, tree species, stand history, and physiographic features improved estimates of mortality. It is hoped that additional infestations of defoliating insects can be studied in order to improve our ability to interpret SCH relationships along with other factors that influence dieback and mortality.

\section{Acknowledgments}

The interest and support of Ontario Ministry of Natural Resources foresters in the Owen Sound and Wingham districts of Ontario, particularly John Lambe and Verde Fisk, are gratefully acknowledged. Robert McCron and Edgar Buchan of Forestry Canada, Ontario Region are thanked for their assistance and counsel.

\section{References}

Dixon, W.J. 1983. BMDP Statistical Software, Univ. Calif. Press, Berkley. 734 p.

Geise, R.L., D.R. Houston, D.M. Benjamin, J.E. Kuntz, J.E. Kaplan and D.D. Skilling. 1964. Studies of maple blight. Univ. Wisc., Madison Res. Bull. 250. 128 p.
Griffin, H.D. 1965. Maple dieback in Ontario. For. Chron. 41: 295-300.

Gross, H.L. 1985. The impacts of insects and diseases on the forests of Ontario. Gov't of Can., Can. For. Serv., Sault Ste. Marie, Ont. Inf. Rep. O-X-366. 96 p. + appendix.

Houston, D.R. 1981. Stress triggered tree diseases: the diebacks and declines. USDA For. Serv., Northeastern For. Exp. Stn., Rep. NE=INF. 41-81. 36 p.

Howse, G.M., H.L. Gross and A.H. Rose. 1981. Ontario Region. In 1977 Annual Report of the Forest Insect and Disease Survey. pp. 53-69. Dep. Environ., Can. For. Serv., Ottawa, Ont.

Howse, G.M., P.D. Syme and H.L. Gross. 1982. Ontario Region. In 1978 Annual Report of the Forest Insect and Disease Survey. pp. 39-54. Dep. Environ., Can. For. Serv., Ottawa, Ont.

Kondo, E.S. and R.G. Taylor. Comp. 1985. Forest insect and disease conditions in Canada 1984. Gov't of Can., Can. For. Serv., Ottawa, Ont. 76 p.

McLaughlin, D.L., S.N. Linzon, D.E. Dimma, and W.L. McIlveen. 1985. Sugar maple decline in Ontario. Ont. Min. Environ., Toronto, Ont. Rep. No. ARB-144-85-Phyto A.P.I.O.S. \#026/85. 18 p.

Morawski, Z.J.R. 1971. Hardwood survey in southern Ontario quality assessment study. Canada Land Inventory (ARDA), Ont. Min. Nat. Resour. and Univ. Toronto. Interim Rep. $100 \mathrm{p}$.

Parker, J. and D.R. Houston. 1971. Effects of repeated defoliation on root and root collar extractions of sugar maple trees. For. Sci. 17: 91-95.

Rowe, J.S. 1972. Forest Regions of Canada. Dep. Environ., Can. For. Serv. Publ. No. 1300. 172 p.

Wargo, P.M. 1975. Estimating starch content in roots of deciduous trees - a visual technique. USDA For. Serv., Northeastern For. Exp. Stn., Res. Pap. NE-313. 19 p.

Wargo, P.M. 1976. Variation of starch content among and within roots of red and white oak trees. For. Sci. 22: 468-471.

Wargo, P.M. 1977. Wound closure in sugar maple: adverse effects of defoliation. Can. J. For. Res. 7: 410-414.

Wargo, P.M. 1978. Judging vigor of deciduous hardwoods. USDA, Washington, D.C. Agric. Inf. Bull. No. 418. 15 p.

Wargo, P. M. 1981a. Defoliation and tree growth. In Gypsy Moth: Research toward Integrated Pest Management. Chapter 5. Effects of defoliation on trees and stands. pp. 225-240. USDA For. Serv., Washington, D.C. Tech. Bull. 1584. $757 \mathrm{p}$.

Wargo, P.M. 1981b. Defoliation, dieback and mortality. In Gypsy Moth: Research toward Integrated Pest Management. Chapter 5. Effects of defoliation on trees and stands. pp. 240-248. USDA For. Serv., Washington, D.C. Tech. Bull. 1584. 757 p.

Wargo, P.M. 1981c. Measuring response of trees to defoliation stress. In Gypsy Moth: Research toward Integrated Pest Management. Chapter 5. Effects of defoliation on trees and stands. pp. 248-267. USDA For. Serv., Washington, D.C. Tech. Bull. 1584. 757 p.

Wargo, P.M., J. Parker and D.R. Houston. 1972. Starch content in roots in defoliated sugar maple. For. Sci. 18: 203-204. 